\title{
O potencjalności Agambena i Deleuze'a
}

Ewa Szumilewicz 


\section{O potencjalności Agambena i Deleuze'a'}

Ewa Szumilewicz

TEKSTY DRUGIE 2017, NR 4, S. 36-54

DOI: $10.18318 /$ td.2017.4.3

naliza zagadnienia potencjalności w świetle Agambena i Deleuze'a odniesiona metaforycznie do funkcji falowej wszechświata (mechanika kwantowa) ukazuje, że pozycja podmiotowa obserwatora powinna być właściwie obierana. Zagadnienie możliwości a potencjalności wymagają odmiennych pozycji podmiotowych ${ }^{2}$. Pozycja Agambena jest paradoksalną figurą pozycji podmiotowej.

Badanie rozpocznę rozbiorem logicznym rozumowania Agambena dotyczącego zagadnienia potencjalności. Rozumowanie owo jest dalekie od krystaliczności w sensie czystych, logicznych struktur myślenia. Udowodnię,

1 Niniejszy artykuł jest częścią pracy doktorskiej pisanej w Instytucie Filozofii i Socjologii PAN. Pragnę podziękować profesorowi Andrzejowi Lederowi za mądrą i cierpliwą opiekę.

2

Odnośnie pozycji podmiotowej: zob. A. Leder Pozycja podmiotowa i podmiotowe pole - wariacje na temat Lacanowski, w: W(okół) współczesnej filozofii francuskiej, Wydawnictwo Naukowe Akademii Pomorskiej w Słupsku, Słupsk 2012.

\section{Ewa Szumilewicz}

- doktorantka

w Instytucie Filozofii

i Socjologii Polskiej

Akademii Nauk.

Projekt doktorski

„O paradoksie po-

znania. Podmiot post-

strukturalny" bada

paradoksalną genezę

podmiotu i jego

relacji ze światem,

pokazuje, że język

nauk przyrodniczych,

którego używa jako

metafory, opowiada

podobną historię.

Ewa Szumilewicz jest

laureatką m.in. sty-

pendium naukowego

Ministra Edukacji. 
że w analizie zagadnienia potencjalności Agamben popełnił elementarny błąd logiczny.

Następnie będę próbować uchwycić moment 'cięcia' w krajobrazie mechaniki kwantowej. W tym celu posłużę się klasyczną interpretacją zasady nieoznaczoności Heisenberga, a mianowicie kopenhaską interpretacją funkcji falowej wszechświata. Dwie odmienne pozycje obserwatora zostaną odniesione do kopenhaskiej interpretacji funkcji falowej oraz do interpretacji wieloświata (Many Worlds Interpretation). Wyprowadzę implikacje filozoficzne takiego zabiegu. Dołączę uwagi podsumowujące.

\section{Potencjalność według Agambena}

Jest to wynik zasługujący na specjalną nagrodę za kunszt, zamierzony lub mimowolny, doprowadzenia wniosków z nieporozumienia do granic ścisłości.

Agamben oparł swoje rozumowanie na prawach Arystotelesa. Powołując się na fragmenty dzieł Arystotelesa, dowodził, że potencjalność (potentiality) jest możliwością (possibility) zarówno dla aktu (act), jak i dla zaprzestania aktu (ceasing the act). Owo 'zaprzestanie aktu' zostało przez Agambena zdefiniowane jako nie-akt (not-act) ${ }^{3}$.

Agamben, opierając się na diagramach Arystotelesa, postuluje stan, który nie może zostać zanegowany, gdyż jest już podwójnie zanegowany. Krok Agambena prowadzi do aporii, których implikacje zarówno logiczne, filozoficzne, jak i ontologiczne będę analizować. Najpierw jednak skoncentruję się na podaniu w wątpliwość krystaliczności struktur rozumowania Agambena. Innymi słowy, przeprowadzę rozbiór logiczny schematów rozumowania Agambena.

Zdanie, które Agamben postuluje jako nieodwracalne (irreparable) brzmi: 'Świat może nie nie-istnieć' ${ }^{4}$ - 'The world is capable of not not-being'. (The

3 G. Agamben Potentialities. Collected Essays in Philosophy, Stanford University Press, Stanford 1999. W nawiasie podaję angielskie odpowiedniki, gdyż esej został najpierw opublikowany po angielsku. Wersja włoska ukazała się dopiero w 2005 roku i również trzyma się konotacji z myślnikiem. Wersja włoska widnieje w tomie: La potenza del pensiero: Saggi e conferenza. Jej redaktorem jest Neri Pozza a wydana została przez Giorgio Agambena.

4 Tłumaczenia na język polski są autorki. Polskie tłumaczenie Wspólnoty, która nadchodzi Sławomira Królaka jest nieprecyzyjne. Tłumacz nie trzyma się konotacji z myślnikiem. 
Coming Community - X Irreparable ${ }^{5}$ - 'esso puo non non-essere ${ }^{6}$ (La comunità che viene - XIrreparabile).

Agambena 'nie nie-istnienie' stoi w opozycji do Arystotelesowskiej zasady niesprzeczności. Zgodnie z Arystotelesem 'Kategorie' 6a-8: 'Niemożliwym jest dla rzeczy być swoim przeciwieństwem”. Jak też i mocniej: „Najmocniejszym ze wszystkich przekonań jest to, że dwa twierdzenia względem siebie sprzeczne nie mogą być równocześnie prawdziwe"8.

Co więcej, jako że w zapisie Agambena 'nie-istnienie' zostało zdefiniowana za pomocą znaku logicznego negacji, zatem owo zdanie Agambena „Świat może nie nie-istnieć” równoznaczne jest ze zdaniem np. „Świat może nie uśmiechać się” czy „Świat może nie tańczyć.” Innymi słowy, „Świat może: cokolwiek poza 'istnieć'”. Jest to oczywiste, gdyż 'nie-istnieć', jeśli trzymać się klarownego formalnego zapisu logicznego, to nie-A czyli 'cokolwiek poza A'.

Jako że 'nie-A' to negacja 'A', zatem 'może nie-istnieć' (ability to not-be) jest opozycją 'może istnieć' (ability to be)". Stąd jest oczywistym, że lamana jest Arystotelesowska zasada niesprzeczności?.

Schemat, na którym opiera się Agamben, to diagramy modalności Arystotelesa. Uogólniony schemat rozumowania z 'De interpretatione'10 22a14-22a32 jest następujący:

czasownik modalny + BEZOKOLICZNIK vs. negacja czasownika modalnego + BEZOKOLICZNIK

czasownik modalny + NEGACJA BEZOKOLICZNIKA vs. negacja czasownika modalnego + NEGACJA BEZOKOLICZNIKA.

Powtórzmy: zarówno dla Arystotelesa, jak i dla Agambena: 'nie-A' to 'negacja A'. Stąd, 'nieA' to 'cokolwiek poza A'. Jeśli zatem 'A' będzie oznaczać 'śpiewanie', to 'nie-A' będzie oznaczać: 'tańczenie, czytanie (cokolwiek poza śpiewaniem)'. Owo postulowane przez Agambena jako nienaprawialne zdanie 'Może nie nie-istnieć' to np.: 'Może nie śpiewać. Agamben interpretuje 'nie-istnieć' jako 'nie-A', a zatem jako 'cokolwiek poza A'.

5 G. Agamben Coming Community, University of Minessota Press, Minneapolis-London 1993.

6 G. Agamben La comunità che viene, Giulio Einaudi editore, Torino 1990, s. 29.

7 "It is impossible for a thing to be its contrary".

8 Arystoteles Metafizyka, Gamma, przeł. K. Leśniak, PWN, Warszawa 1983, 1011 b.

9 Agamben bowiem dowodzi, że zarówno możność aktu, jak i możność nie-aktu znajdują się w jednym i tym samym bycie (człowieku) równocześnie. 
Widać wyraźnie, że notacja Agambena jest błędna. Jedyny poprawny zapis, który mógłby 'uratować' myślenie Agambena, który jest zapisem poprawnym, w sensie czystości struktur myślenia to potraktowanie 'nie-A' jako 'nieA'. Jednakowoż w takiej sytuacji zdanie Agambena przestaje być nienaprawialnym zdaniem, przestaje być zdaniem, dla którego zaprzeczenie nie istnieje, gdyż potrzebna by była potrójna negacja (nie-A bowiem to zaprzeczenie A, zaś nieA nie jest zaprzeczeniem).

Załóżmy jednak teoretyczną wersję: 'nieA' jako zapis dla 'zaprzestania aktu'. Takowy zapis uratowałby koherentność rozumowania Agambena, choć wykraczałby poza ontologię Arystotelesa. Powróćmy do zdania Agambena: 'Świat może nie nie-istnieć', które teraz brzmiałoby ‘Świat może nie nieistnieć.'Zdanie to podlega analizie w diagramach negacji Arystotelesa:

czasownik modalny + NEGACJA BEZOKOLICZNIKA (tutaj bezokolicznikiem jest 'nieistnienie') vs. negacja czasownika modalnego + NEGACJA BEZOKOLICZNIKA.

Zastępując notację Agambena 'nie-A' notacją 'nieA', otrzymujemy: 'Świat może nie nieistnieć., którego opozycją jest 'Świat nie może nie nieistnieć.'

Nie jest to oczywiście potrójna negacja. 'Nieistnieć' to jedno słowo, jeden czasownik, a nie negacja czasownika. Zdanie Agambena w takim świetle to zdanie naprawialne, tzn. takie, które można zanegować.

Trzeba jednak zauważyć (dziękuję za tę uwagę profesorowi Andrzejowi Lederowi), że 'nieistnieć', owo 'nieA' rozumiane jako 'nieczasownik', to tradycja nowożytna, Heglowska, a następnie Heiddegerowska. 'Niebyć' rozumiane jako pozytywność negacji nie mieści się w ontologii Arystotelesa. Stąd nawet taki sposób 'ratowania' myślenia Agambena zawodzi.

Co więcej, w ‘O interpretacji’ Arystotelesa 18b13-18b15 czytamy: „Jeśli coś nie może nie wydarzyć się to jest niemożliwym, aby się nie wydarzyło; a jeśli coś jest niemożliwe, aby się nie wydarzyło to jest koniecznym, aby się wydarzyło"11. Stąd 'jeśli nie może nie wydarzyć się, to 'koniecznym jest, aby się wydarzyło'. Zatem: 'Świat może nie nie-istnieć' odpowiada. 'Świat jest koniecznym, aby istnieć', który ma opozycję w: 'Świat nie jest koniecznym, aby istnieć.'

Zrekonstruujmy rozumowanie Agambena:

Aksjomat 1. Istnieje 'może istnieć'.

Aksjomat 2. Istnieje 'może nie-istnieć'.

11 "But if something cannot not happen it is impossible for it not happen; and if it is impossible for something not to happen it is necessary for it to happen". 
Aksjomat 3. (Jest to entymematyczna przesłanka, ponieważ Agamben jej nie wyartykułował.) Obowiązuje Arystotelesowska zasada niesprzeczności.

A warto cały czas mieć na uwadze, że Agamben powinien trzymać się ram aksjomatycznych wyznaczonych przez Arystotelesa, jeśli jego celem jest wyprowadzenie implikacji filozoficznych systemu Arystotelesa. Jeśli bowiem staramy się szukać implikacji dla danego systemu logicznego (tu: system Arystotelesa), musimy trzymać się aksjomatów (tu: zasady niesprzeczności), jakie w danym systemie obowiązują. W innym przypadku popełniamy błąd logiczny, elementarny.

Podstawmy zatem (trzymając się notacji Agambena)

1. 'może istnieć' jako 'p'

2. 'może nie-istnieć' jako 'nie-p'

ZASADA NIESPRZECZNOŚCI: nieprawda, że 'p' i 'nie-p'.

Jest oczywiste, że aksjomaty nie mogą być sprzeczne. Zatem, aby rozumowanie Agambena było spójne, aby można było rozważać nie-akt (owo 'ability to cease the act'), to z konieczności musi zostać uchylona przynajmniej psychologiczna zasada niesprzeczności. Próby uchylenia psychologicznej zasady niesprzeczności były podejmowane w nowożytnej filozofii (np. Jan Łukasiewicz). Jednakowoż w obrębie myśli, systemu Arystotelesa zasada niesprzeczności jest jednym z koronnych filarów jego filozofii. Zatem oczywiste jest, że albo jedno z założeń Agambena jest fałszywe (albo nie istnieje 'może istnieć', albo 'może nie-istnieć'), albo nie obowiązuje zasada niesprzeczności.

Reasumując: Agamben popełnił elementarny błąd logiczny. A mówiąc inaczej, mówiąc wbrew Agambenowi, świat niekoniecznie musi istnieć. Możliwy jest zarówno stan, gdy świat istnieje, jak i taki, gdy świata nie ma. Ponura konieczność czy też, i mocniej, ponury przymus, który jest osiowym elementem filozofii Agambena powstał na kanwie elementarnego błędu logicznego. Agambenowskie badanie, błędne badanie funkcji potencjalności prowadzące do funkcji konieczności i przymusu istnienia świata dało filozofowi impuls do stworzenia teologii politycznej jako tej, która, mówiąc najogólniej, ma być panaceum na ponurą konieczność istnienia. Projekt Agambena to projekt, którego kamieniem węgielnym jest elementarny błąd logiczny i jako taki, ów projekt stoi, co najmniej, pod znakiem zapytania.

Innymi słowy, Agamben bazując na prawach logicznych (diagramach modalności Arystotelesa) logiki Arystotelejskiej, dowodzi 'nienaprawialności' świata, uchylając równocześnie zasadę niesprzeczności Arystotelesa. Agamben popełnił błąd, wybiórczo stosując aksjomaty logiki Arystotelejskiej. Stąd koncepcja potencjalności Agambena jest od podstaw błędna. 


\section{Akt 'cięcia' w deleuzjańskim krajobrazie}

Przyjrzyjmy się relacji pojęcie - płaszczyzna immanencji12. Plaszczyzna immanencji jest to płaszczyzna czystej potencjalności. W momencie, gdy obserwator tworzy pojęcia na płaszczyźnie immanencji, to pojęcia jemu możliwe stają się pojęciami aktualnymi. Obserwator, używając przemocy, aktu, który Deleuze przejmuje po Nietzschem, wciela pojęcia jemu możliwe jako własne, jako aktualne.

Chrzest pojęć wymaga specyficznego filozoficznego smaku uciekającego się do przemocy albo do pochlebstw. ${ }^{13}$

Innymi słowy, z siłą 'cięcia' (akt tworzenia pojęcia) potencjalne pojęcia stają się aktualne. To jest moment, w którym 'zewnętrzne' (możliwość pojęcia jako taka) staje się ‘wnętrzem' (pojęcie wcielone dla obserwatora).

Potraktujmy rzecz krótko: rozważmy pole doświadczenia uznanego za świat rzeczywisty już nie w odniesieniu do „ja”, lecz do prostego „istnieję...". W takim czy innym momencie istnieje świat spokojny i pozostający w spoczynku. Nagle wyłania się przerażona twarz, która spogląda na coś znajdującego się poza polem. Drugi nie ukazuje się tutaj ani jako podmiot, ani jako przedmiot, lecz - co jest czymś zupełnie innym - jako świat możliwy, jako możliwość przerażającego świata. Ów świat możliwy nie jest rzeczywisty lub jeszcze taki nie jest, a jednak istnieje: to coś wyrażonego, co istnieje tylko w swoim wyrazie, twarz albo równoważnik twarzy. ${ }^{14}$

Jako metafory możemy tutaj użyć momentu kolapsu funkcji falowej wszechświata. Jest to bowiem moment, w którym funkcja potencjalności, funkcja wszelakich możliwych potencjalnie wszechświatów zapada się do wszechświata obserwatora, który to obserwator z biernego, zewnętrznego staje się obserwatorem uczestniczącym, aktywnym graczem wszechświata mu już aktualnego. W momencie kolapsu ze zbioru wszechświatów możliwych, w stosunku do których był on na pozycji zewnętrznej, staje się on

G. Deleuze, F. Guattari Co to jest filozofia, słowo/obraz terytoria, Gdańsk 2000, s. 43-70.

13 Tamże, s. 15.

14 Tamże, s. 23. 
podmiotem zamieszkującym wszechświat mu aktualny. Pozostałe wszechświaty, będące dla niego wcześniej możliwościami, zapadają się teraz i stają się dla niego wszechświatami niemożliwymi. Gdy przyjrzymy się uważnie, ów przykład jest również ilustracją zagadnienia potencjalności (potentiality) a możliwości (possibility), jako że wymagają one odmiennej pozycji podmiotowej. Do owych dwóch pozycji podmiotowych powrócimy.

Przyjrzymy się deleuzjańskiej relacji Aion - Chroons. Czas w ujęciu Deleuze'a objawia się jako Aion i jako Chronos. Aion to, używając Deleuzjańskiej terminologii, zawsze neutralny Bezokolicznik, pusta forma czasu, a jako taki nieograniczony i niezależny od materii. Aion jest czasem wydarzeń-efektów: rozpościera się w przeszłość i przyszłość i z takowej perspektywy dokonuje podziału teraźniejszości. Wszystkim tym, czy nie jest Aion, jest natomiast Chronos. Chronos nie jest zatem Bezokolicznikiem - jest zawsze określony: czynny albo bierny. Chronos nie jest również pustą formą czasu - Chronos to wiecznie żywa teraźniejszość. Jak Aiona nie ograniczała materia, gdyż nie był on od niej zależny, tak Chronos od materii zależy. Materia ogranicza i wypełnia Chronosa, on sam zaś odmierza ruch ciał. Poruszając się nadal w terminologii Deleuze'a, obrazowo można ująć Chronosa jako wyłącznie szkatułkowe teraźniejszości. Napięciu Aion - Chronos nie trzeba przydawać elementu nieparalelności czasowej, jest to raczej wzajemna nieodpowiedniość elementu A (Aion) i elementu B (Chronos), choć nie sposób rozważać jednego bez drugiego: nie sposób rozważać Aiona bez Chronosa, jak i Chronosa bez Aiona. Oba czasy, zarówno Aion, jak i Chronos, są to odrębne wykładnie czasu, przy czym każda z nich jest równocześnie i komplementarna i dysjunktywna.

Synteza dysjunktywna to procedura sięgająca intuicji nietzcheańskiej.

„Procedura”, o której mowa to samo życie. Już Leibniz nauczył nas, że nie istnieją punkty widzenia na rzeczy, a tylko rzeczy, byty, które same są punktami widzenia. U Leibniza punkty widzenia wciąż jeszcze podlegały jednak regule wykluczenia, zgodnie z którą mogły otwierać się na siebie nawzajem tylko dzięki zbieżności - jak punkty widokowe wychodzące na jedno miasto. U Nietzschego, wprost przeciwnie, punkt widzenia otwiera się na afirmowaną przezeń rozbieżność: przed każdym z punktów widokowych rozpościera się inne miasto, każdy z punktów widzenia jest innym miastem, a jedyne co wiąże te wszystkie miasta ze sobą, to odległość między nimi, współbrzmią one ze sobą tylko dzięki rozbieżności swych serii, swych ulic i domów. Zawsze jakieś inne miasto w mieście. 
Każdy człon umożliwia dotarcie do ostatecznych krańców innego członu, przejście całego dystansu. Ta perspektywa - albo perspektywizm - staje się u Nietzschego sztuką głębszą jeszcze aniżeli Leibnizjańskie punkty widzenia; rozbieżność przestaje być tu zasadą wykluczenia, a dysjunkcja przestaje oddzielać, niewspółmożliwe staje się ośrodkiem komunikacji. ${ }^{15}$

Synteza dysjunkcyjna uwrażliwia na 'afirmowane rozbieżności'. Owo 'niewspółmożliwe' zostaje przez Deleuze’a ujęte jako wartość dodana. Synteza dysjunktywna otwiera również drzwi myśleniu dywergencyjnemu. Ów perspektywizm to swoisty punkt widzenia, w którym afirmowane rozbieżności, a precyzyjniej punkty węzłowe rozbieżności, wyznaczają kierunek rozwidlania się następnych, kolejnych rozbieżności. Deleuze, opierając się na rozumowaniu dywergencyjnym, postuluje ujmować perspektywizm jako warunek jawienia się podmiotowi pewnej prawdy zmienności. Stąd synteza dysjunktywna nie jest jedynie narzędziem myślenia, bez troski o prawdziwościowy charakter kształtu myśli, ale raczej jest konwergencją prawdziwościową. „W ślad za dogłębną zmianą statusu przedmiotu zmienia się również status podmiotu" postuluje Deleuze ${ }^{16}$. Operację syntezy dysjunktywnej metaforycznie można ująć jako fraktalną konstrukcję obrazu myśli, gdzie rezultatem takiej operacji jest wyłaniający się obraz jako taki.

Nadal jednak poruszamy się w zamkniętej, dusznej, jednotorowej przestrzeni, niczym po wytartym kole hermeneutycznym - gdzie z jednej strony roztapia nas zimne, szkatułkowe 'tu i teraz', a z drugiej, próbujemy owe szkatułkowe, fraktalne płatki 'tu i teraz' czynić metodą eksplorowania całości; jako zbieżne punkty widokowe, których pusta przestrzeń pomiędzy jest pierwszą znaczącą, gdyż czyni przedmiotem afirmacji dzielący je dystans. Jednakże tkwi tutaj paradoksalny tragizm - owa pusta znaczaca jest afirmowana jako pierwsza znacząca, a owa pusta znaczaca ma swoje źródła w zimnym ratio chronosowego cięcia ${ }^{17}$. Pytanie zatem jawi się następujące:

w jaki sposób indywiduum może przekroczyć swoją własną formę i zerwać związki syntaktyczne ze światem, dochodząc tym samym do uniwersalnej komunikacji wydarzeń, czyli do afirmacji syntezy dysjunktywnej

G. Deleuze Logika sensu, PWN, Warszawa 2011, s. 236. Innymi słowy, realność pustki fundowana jest na realności rozumu, co już trwoży mniej. 
nie tylko poza porządkiem sprzeczności logicznej, ale nawet niezależnie od alogicznych niezgodności. Indywiduum musiałoby pojąć samo siebie jako wydarzenie. Owo zaś urzeczywistniające się w nim wydarzenie musiałoby je z kolei pojąć jako zaszczepione na nim, inne indywiduum, pragnąc zarazem wszelkich innych indywiduów jako wydarzeń, rozumiejąc je i przedstawiając je sobie jako wydarzenia. Każde indywiduum byłoby niczym lustro, w którym skupiają się osobliwości, a każdy świat - jak odległość w lustrze. ${ }^{18}$

Czy rzeczywiście rację miał Deleuze, twierdząc, że indywiduum, przekraczając własną formę i zrywając związki syntaktyczne ze światem, dochodzi do uniwersalnej komunikacji wydarzeń?

Prosty schemat logiki klasycznej (zasada niesprzeczności ${ }^{19}$ ) wyklucza zasadność zadania takiego pytania. Wracając zatem do deleuzjańskiego pejza$\dot{z} u$, pytanie o owe odległości między miastami jawiłoby się jako bezzasadne. Trzeba by zatem przyjąć, że nie ma sensu pytać o to, co znajduje się między obiektami w mieście. Nie miałoby znaczenia, czy znajduje się tam trawnik, las bądź np. ulice. Gdyby zaś przenieść ów problem w rejony np. matematyki, to synteza dysjunktywna byłaby pytaniem o właściwości i atrybuty przestrzeni, w której znajdują się elementy danego zbioru. Jest to pytanie - z punktu widzenia matematyki - na ogół pomijane. Przykładowe trzy elementy będą podlegać takiej samej analizie niezależnie czy znajdują się one w próżni, wodzie czy gdziekolwiek indziej.

Jednakowoż Deleuze zaznacza, że procedura syntezy dysjunktywnej odnosi się raczej do sfery życia niż do aksjomatów jako takich. Niejednokrotnie na łamach Logiki Sensu podejmowane były zagadnienia dotyczące nieprzewidywalności. Pusta przegródka, punkt aleatoryczny to momenty, w których prawa formalne uginają się.

Czy też, byłoby to pytanie o ową przestrzeń między trzema punktami pytanie o wodę, próżnię czy też np. powietrze.

18 G. Deleuze Logika sensu, PWN, Warszawa 2011, s. 242.

19

W pierwszym odruchu wydawać by się mogło, że jest z mojej strony sprzecznością rozliczać Agambena z nieuznawania zasady niesprzeczności i równocześnie odnosić się przychylnie do prób uchylania tejże zasady czynionych przez Deleuze'a. Tak nie jest. Mój zarzut w stosunku do Agambena to zarzut operowania systemem aksjomatycznym (tu systemem logiki formalnej Arystotelesa, systemem, w którym zasada niesprzeczności obowiązuje) przy równoczesnym odrzucaniu części aksjomatów (zasady niesprzeczności). 
Operacja syntezy dysjunktywnej uwrażliwia na problem 'tła'. Usuwanie elementów z przestrzeni nie jest li tylko usuwaniem elementów jako takich, ale jest to równocześnie sytuacja, w której odkrywa się przestrzeń owe elementy otaczająca. Zapominanie o budynkach to równocześnie możliwość wrażliwego wpatrywania się w owe lasy, ulice, trawniki - te lasy, które na co dzień bledną i zanikają pod naporem domów. Deleuzjańske spojrzenie wprowadza w rzeczywistość, w której odkrywanie palimpsestów staje się możliwe. Co więcej, jedynie w świetle deleuzjańskiej syntezy dysjunktywnej możliwe jest współistnienie Chronosa i Aiona. Zaryzykowałabym zatem tezę, że deleuzjański sens wyłania się z połączenia Aiona i Chronosa na mocy syntezy dysjunktywnej, gdzie w owym 'splocie' czy też na granicy (która nie jest oddzieleniem) owych dwóch czasów wyłania się sens jako miejsce artykulacji.

Deleuzjański sens wyłania się na granicy Aiona i Chronosa. Wraz z chronosowym cięciem, wydarzenie aionowe zostaje wyartykułowane. Myśl zostaje oszlifowana do kształtu słowa.

Dzielił je [Aiona i Chronosa] co najwyżej różny kierunek: w przypadku Aiona stawanie-się-szaloną głębi wypływało ku powierzchni, symulakry stawały się fantazmatami, głębokie zaś rozcięcie pojawiało się na powierzchni pod postacią pęknięcia. ${ }^{20}$

Nie należy zapominać, że taka struktura cechuje się skrajną kruchością, o czym przypomina ostatnie zdanie dwunastej serii Logiki Sensu: „Ów schemat całkowitego rozpostarcia na powierzchni cechuje w sposób nieunikniony i w każdym punkcie musi cechować skrajna i niedająca się usunąć nietrwałość".

Dzieje się tak dlatego, że przeszłość, przyszłość i teraźniejszość nie są według Deluze’a, który podąża za stoikami, trzema częściami jednej czasowości ${ }^{21}$, ale umożliwiają dwie różne interpretacje czasu, z których każda jest komplementarna i dysjunktywna: Chronos, jako z definicji zawsze ograniczona teraźniejszość, który mierzy działania ciał jako przyczyn oraz mierzy stan ich głębinowych konstelacji, oraz Aion, który ze swoich czeluści zbiera na powierzchnię bezcielesne wydarzenia jako efekty.

Ponieważ wykładnia przeszło-przyszła (Aion) i teraźniejsza (Chronos) to dwa dysjunktywne sposoby oglądu świata, to rzec możemy, że albo istnieje

G. Deleuze Logika sensu, s. 224. 
jedynie ‘teraz’ mierzące przeszło-przyszłe konstelacje bądź też, że istnieją jedynie przeszło-przyszłe podziały układające się wzdłuż pustych linii wirtualnych 'teraz'.

W jednym przypadku „teraz ogarnia wszystko, przeszłość zaś i przyszłość świadczą jedynie o względnej różnicy dzielącej dwie chwile teraźniejsze: jedną o mniejszej rozciągłości i drugą, której kontrakcja ogarnia znacznie większy obszar. W drugim natomiast teraźniejszość jest niczym, czystym matematycznym momentem, bytem rozumowym wyrażającym przeszłość i przyszłość, na które wciąż się dzieli. Innymi słowy mamy dwa czasy: na pierwszy z nich składają się wyłacznie szkatutkowe teraźniejszości, podczas gdy drugi bezustannie rozkłada się na rozpostarta przeszłość i przyszłość. Podczas gdy pierwszy jest zawsze określony, czynny lub bierny, drugi to wieczny, zawsze neutralny Bezokolicznik. Jeden to cykliczny, odmierza ruch ciał i zależy od materii, która go ogranicza i wypełnia, a drugi ma postać czystej linii prostej na powierzchni, pozostaje bezcielesny i nieograniczony, niczym pusta forma czasu, niezależna od wszelkiej materii. ${ }^{22}$

Chronos to zatem taka teraźniejszość, która mierzy niczym precyzyjny szwajcarski zegarek głębinowe, przeszło-przyszłe formy, tnąc je na powierzchni na cieniutkie, pojedyncze 'teraz'. Można zaryzykować stwierdzenie, że za cenę całościowej jedności struktury (Chronos jako linia prosta rozpościera się ku nieskończoności, jest prostą nieskończoną) obdzieramy byt z jego całościowej istoty: szatkujemy go na szkatułkowe teraźniejszości tak, by poddawać go zimnej, matematycznej, precyzyjnej, chronosowej kalkulacji. Takie ujęcie czasu jest cokolwiek zbliżone do intuicji paradoksu z paradoksu strzały.

$\mathrm{Z}$ drugiej strony pusta wieczność aionowego czasu poraża swoją mocą bezkresu. Brak tam owej matematycznie wymodelowanej przegródki, gdzie byty mogą być poddawane nijakiej obróbce. Aion takiego miejsca w sobie nie ma. Aion zionie pustką, niczym niesformatowany dysk komputerowy. Aion to miejsce głębi, w której diament nie zostanie odarty z przysłowiowych siedmiu gramów, ale to równocześnie i taka głębia, w której można zatonąć.

Napięcie między Aionem i Chronosem skutkuje narodzinami słowa. Czas głębinowy (Aion) można postrzegać jako zbór wszelakich możliwych konfiguracji raczej niż konfiguraje jako takie. Aion to zbiór wszystkich możliwości, które aktualizują się za pomocą cięcia Chronosa. Deleuzjański czas odnieść 
można metaforycznie do kopenhaskiej interpretacji mechaniki kwantowej. Funkcja falowa wszechświata jest zbiorem wszelakich możliwych potencjalnie światów, które w akcie 'cięcia', w akcie pomiaru aktualizują się do określonego, konkretnego kształtu świata.

\section{'Cięcie' w mechanice kwantowej. Pozycja obserwatora i agambenowy błąd}

Mechanika kwantowa nie pozwala na przewidzenie rezultatu pojedynczego pomiaru. Jest to teoria, która oddaje prawdopodobieństwo możliwego rezultatu. Czas i przestrzeń nie są wpisane w krajobraz mechaniki kwantowej. Obserwator jest zewnętrzną ramą odniesienia. Zdarzenie jest zawężone do czasu i przestrzeni, w jakiej badane jest przez obserwatora. Obserwator jest używając terminologii filozoficznej - transcendentalna ramą odniesienia.

Dla porównania, Ogólna Teoria Względności nie ma ramy odniesienia jako takiej, gdyż czas jest częścią gry, czas jest aktywnym graczem. Obserwator jest bowiem częścią zdarzenia. Nie ma konieczności ani możliwości zewnętrznej ramy odniesienia, jako że obserwator jest aktywnym graczem. Niekwestionowana jest stabilność świata, gdyż czas jest wcielony w ramy struktury. Warto jednak mieć cały czas na uwadze, że w ramach tej teorii jest to zawsze czas względny.

Mechanika kwantowa to teoria poza czasem i przestrzenią. Potrzebna jest zewnętrzna rama odniesienia (jako 'cięcie'), aby uchwycić wydarzenie. Czas kaleczy wydarzenie. Stąd, pochwycić wydarzenie, to zranić. Świat mechaniki kwantowej to świat niestabilny i kruchy, jako że może zostać uchwycony jedynie z perspektywy upływu czasu. Struktura jako taka wyłania się, gdy zamrażana jest w aktualizującej i szatkującej teraźniejszości, niczym Deleuzjański akt chronosowy.

Widoczne są dwie pozycje podmiotowe: gdy podmiot jest wewnętrzną częścią świata, aktywnym graczem (ogólna teoria względności), bądź też, gdy podmiot jest zewnętrzną ramą odniesienia (mechanika kwantowa).

Kolaps kwantowy (kolaps funkcji falowej wszechświata) następuje, gdy obserwator będący zewnętrzną ramą odniesienia staje się aktywnym graczem; a czas staje się częścia gry. Wtedy też świat możliwości wszelakich zawęża się do świata danego obserwatorowi (teraz jeż będącemu wewnątrz takowego świata), a wszelakie inne możliwości (inne światy) stają się teraz niemożliwościami, gdyż - następuje ich kolaps.

Interpretacja Wieloświata (Many Worlds Interpretation czy też Multiverse) to ta, gdzie obserwatora brak. Jeśliby ustawić obserwatora w świecie jednym z wielu, to dostrzec można, że jego świat stoi w opozycji do tych 
wszystkich światów, w których się on nie znajduje, do światów niewybranych. Innymi słowy, z wszystkich możliwych mu światów, z wszystkich światów (z jego perspektywy jako teraz jeszcze 'zewnętrznej’) potencjalnych świat wybrany staje się teraz światem aktualnym. Błąd Agambena polega na ustawieniu obserwatora jako aktywnego podmiotu we wszystkich światach możliwych. Jest to niemożliwa pozycja podmiotowa. Błąd Agambenowy to gest nadania życia wszystkich światom możliwym. Owe światy jako aktualnie istniejące mogą być jedynie jako dla obserwatora 'światami niemożliwymi'. Agambenowy podmiot to aktywny gracz równocześnie we wszystkich wszechświatach. Jako metafory można użyć krajobrazu mechaniki kwantowej z wpisanymi czasem i przestrzenią. Jest to zabieg paradoksalny.

Darować śmierć Derridy ${ }^{23}$ obrazuje dylemat pozycji podmiotowej podmiotu poznania. Paradoksalna figura Abrahama to ta, gdzie obserwator jest zewnętrzną ramą odniesienia w stosunku do siebie samego. W procesie wkraczania na górę Moria Abraham zbliża się do zewnętrznej ramy odniesienia (tu założonej jako Bóg). Aby osiągnąć taką pozycję, musi on 'zabić' swój świat, 'darować śmierć świata' Bogu.

Jacques Derrida w swoim eseju przywołuje sytuację daru jako równoczesnej zdrady każdego, któremu równocześnie dar odbieram. Mówiąc prościej i w myśl Marcela Maussa, sytuacja daru, sytuacja skądinąd niemożliwa, to zawsze równocześnie sytuacja zdrady:

Dając śmierć i zdradzając, nie muszę wcale sięgać po nóż, ani zwracać ostrza w stronę mego syna na górze Moria. Dniem i nocą, w każdej chwili, na wszystkich górach Moria tego świata, tak właśnie postępuję, podnosząc dłoń przeciwko temu, co kocham i powinienem kochać, przeciw tym, którym winien jestem absolutną wierność. [...] Nie szukajmy przykładów, jest ich zbyt wiele na każdym kroku. Być może spełniam mój obowiązek, robiąc w tej chwili to, co robię, wybierając moją pracę, poświęcając jej czas i uwagę, preferuję moją działalność jako obywatela, pracownika naukowego i zawodowego filozofa, posługując się językiem ojczystym, w moim wypadku - francuskim. Lecz jednocześnie poświęcam i zdradzam wszystkie inne moje zobowiązania: wobec innych, których znam i nie znam $[\ldots] .^{24}$

23 Zob.http://www.historiasztuki.uni.wroc.pl/sklad/cw/doc/Cezary_Was_Czytanie_Derridy.pdf (10.02.2017).

24 Czytanie Derridy, red. B. Małczyński, R. Włodarczyk, Wrocław 2005, s. 81. Zob. http://www.historiasztuki.uni.wroc.pl/sklad/cw/doc/Cezary_Was_Czytanie_Derridy.pdf (21.09.2017). 
Można taką sytuację odnieść metaforycznie do odwróconego kolapsu kwantowego, procesu wychodzenia z czasu. Jest to niemożliwy moment, jako że Abraham staje się zewnętrzną ramą odniesienia do świata, który już został przez niego 'zabity'. Abraham staje się zatem swoją własną ramą odniesienia do siebie samego. Innymi słowy, Abraham staje się ramą odniesienia jako taką. Czy też (zakładając Boga) tylko Bóg jest ramą odniesienia dla Abrahama.

Abraham jest tym, który wyszedł z ramy odniesienia (świata). Natomiast Agamben to ten, który ustawił jednocześnie ramy odniesienia we wszelakich światach możliwych, czy też jest to ten, który równocześnie 'jest i nie-jest' w każdym i wszystkich światach równocześnie.

Innymi słowy, pozycja podmiotowa Abrahama to pozycja poza ramą odniesienia, a pozycja Agambena to pozycja wszelakich i wszystkich ram odniesienia równocześnie.

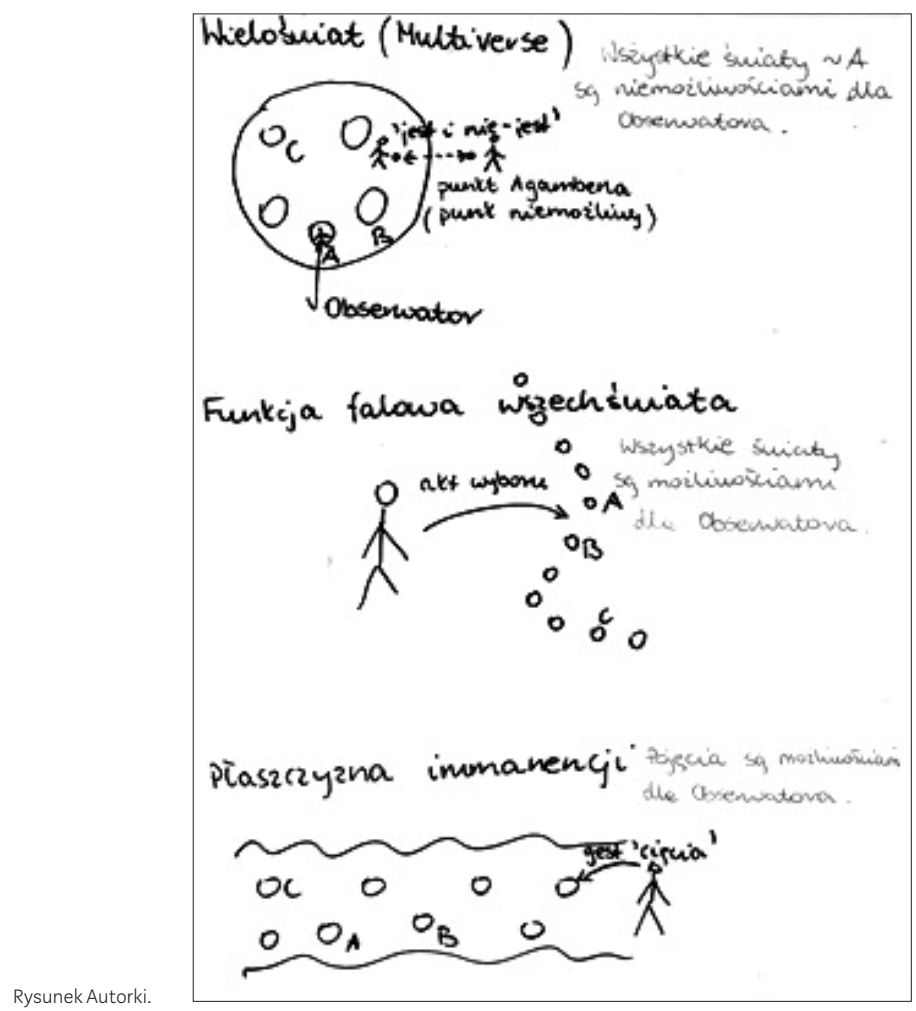




\section{Wnioski końcowe}

Dwie drogi w żółtym lesie szły w dwie różne strony:

Żałując, że się nie da jechać dwiema naraz

I być jednym podróżnym, stałem, zapatrzony

W głąb pierwszej z dróg, aż po jej zakręt oddalony,

Gdzie widok niknął w gęstych krzakach i konarach;

Potem ruszyłem drugą z nich, nie mniej ciekawą,

Może wartą wyboru z tej jednej przyczyny,

Że, rzadziej używana, zarastała trawą;

A jednak mogłem skręcić tak w lewo, jak w prawo:

Tu i tam takie same były koleiny,

Pełne liści, na których w tej porannej porze

Nie znaczyły się jeszcze śladów czarne smugi.

Och, wiedziałem: choć pierwszą na później odłożę,

Drogi nas w inne drogi prowadzą-i może

Nie zjawię się w tym samym miejscu po raz drugi.

Po wielu latach, z twarzą przez zmarszczki zoraną,

Opowiem to, z westchnieniem i mglistym morałem:

Zdarzyło mi się niegdyś ujrzeć w lesie rano

Dwie drogi; pojechałem tą mniej uczęszczaną-

Reszta wzięła się z tego, że to ją wybrałem.

25 Two roads diverged in a yellow wood, And sorry I could not travel both And be one traveller, long I stood And looked down one as far as I could To where it bent in the undergrowth;

Then took the other, as just as fair, And having perhaps the better claim, Because it was grassy and wanted wear; Though as for that the passing there Had worn them really about the same,

And both that morning equally lay In leaves no step had trodden black. Oh, I kept the first for another day! Yet knowing how way leads on to way, I doubted if I should ever come back. 
Droga nie wybrana to wiersz prześmiewczy. Frost napisał ów wiersz z myślą o swoim chronicznie niezdecydowanym przyjacielu, poecie Edwardzie Thomasie. Krajobraz wiersza będzie dla mnie metaforycznym punktem odniesienia dla zagadnienia potencjalności, ale i również jest to metafora paradoksalnego statusu poznania podmiotu poznania.

W Co to jest filozofia Deleuze'a widnieje piękne, boleśnie piękne zdanie:

Elle a des fous rires qui emportent ses larmes. ${ }^{26}$

(szalonym śmiechem tłumi własne łzy)

W jednej z ulubionych scenerii Deleuze'a, opowiadaniu Jorge Borgesa możemy przeczytać:

Ogród o rozwidlających się ścieżkach jest ogromną zagadką czy parabolą, której tematem jest czas; ta ukryta przyczyna zabrania Tu'ui Penowi wspominać jego nazwę. Pomijanie zawsze jakiegoś słowa, odwoływanie się do nieporadnych metafor i do oczywistych peryfraz jest, być może, najbardziej emfatycznym sposobem wskazywania na nie.

Niniejszy artykuł jest próbą pokazania, że gest 'cięcia' jest wpisany w ludzkie poznanie. Jak też i pokazania, jak gest 'cięcia' wpisany jest w struktury nauk przyrodniczych. A w tle niczym echo odbija się pytanie o niedonazywalność, owe diamentowe odpryski, które niczym derridiańskie popioły unoszą się po świecie jako 'cena' płacona za brylanty. Drogi filozofii a nauk przyrodniczych nie są tożsame. Jednak struktura myślenia zdumiewa podobieństwem.

Mechanika kwantowa to teoria 'poza czasem i przestrzenią'. Ponieważ czas jest zewnętrzną ramą odniesienia, to struktura jest iluzją. Bez czasu i przestrzeni widniejących (mechanika kwantowa) potrzebna jest zewnętrzna rama odniesienia (czas i jako metafora Deleuzjański akt Chronosa). Wtedy też niepewność, nieoznaczoność jest nieunikniona (zgodnie z zasadą Heisenberga w mechanice kwantowej, a w świetle filozofii Deleuze'a jest

I shall be telling this with a sigh

Somewhere ages and ages hence:

Two roads diverged in a wood, and I-

I took the one less travelled by,

And that has made all the difference

Robert Frost: "The Road Not Taken".

G. Deleuze, F. Guattart Qu'est-ce que la philosophie?, Les Éditions de Minuit, Paris 2005, s. 16. 
to kruchość i nietrwałość powierzchni, napięcia powierzchniowego między Aionem i Chronosem $\left.{ }^{27}\right)^{28}$.

Deleuze boleśnie wyartykuował ów paradoks. W eseju Michel Tournier i świat bez bliźniego czytamy: „Kolosalnym błędem wszelkich teorii poznania jest postulowanie równoczesności podmiotu i przedmiotu, podczas gdy jeden powstaje wyłącznie kosztem drugiego”. I dalej: „Bliźni zapewnia zatem odróżnienie świadomości od jej przedmiotu jako odróżnienie czasowe. Pierwszy efekt jego obecności odnosi się do przestrzeni i rozmieszczenia kategorii percepcji; drugi efekt, może nawet głębszy, dotyczy natomiast czasu i rozkładu jego wymiarów, uprzedniości i następstwa w czasie. Jakże miałaby jeszcze istnieć przeszłość, kiedy przestaje działać bliźni?"29.

Robinson w ujęciu Deleuze'a to rozbitek, którego struktura bliźniego uległa rozpuszczeniu. Zatem relacja podmiot - przedmiot staje się relacją niemożliwą. Jako że zaniknął element pośredniczący-bliźni, to świadomość nie ma możliwości odróżnienia obiektu - wyspy od Ja-Robinsona. Nie ma przeszłości, czas nie płynie, a Robinson staje się Speranzą:

Robinson jest tylko świadomością wyspy, ale świadomość wyspy jest jej świadomością samej siebie, czyli wyspą samą w sobie. Teraz dopiero pojmujemy paradoks bezludnej wyspy: rozbitek, o ile jest sam, o ile zatracił strukturę-bliźniego, nie przeczy wcale jej bezludności, lecz ją sankcjonuje. Wyspa nazywa się Speranza, ale kim jest Ja? „Nie jest to bynajmniej pytanie pozbawione sensu. Co gorsza, jest to pytanie, na które można znaleźć odpowiedź. Albowiem jeśli to nie jest Robinson to jest to Speranza".30

Wracając do wiersza Frosta. Jest to pewnego rodzaju kpina, ale taka raczej delikatna, czuła. Najwyższe napięcie pojawia się w utworze, gdy podróżnik wpatruje się najdalej jak potrafi w horyzont. Wzrok jest tutaj głównym bohaterem. Wzrok liczy się najbardziej.

"Ów schemat całkowitego rozpostarcia na powierzchni w sposób nieunikniony musi cechować skrajna i niedająca się usunąć nietrwałość". G. Deleuze Logika sensu, s. 120. odniesienia jest i niepotrzebna, i niemożliwa (jako, że 'zewnętrzna jako takiego' brak). Jednakowoż czas jest czasem względnym. 
Dwie wspaniałe książki zostały opublikowane w tym samym roku: Memories of the Blind Derridy i Co to jest filozofia? Deleuze’a. W obu łzy utożsamiane są z czymś więcej niż smutek. Derrida we spojrzeniu otulonym łzami („gaze veiled by tears") widzi prawdę oka: oka, które ani widzi, ani nie widzi, jest obojętnym na zamglony obraz („neither sees nor does not see: it is indifferent to its blurred vision" ${ }^{\prime 31}$ ). Otulony łzami wzrok Derridy jest to akt czystej możliwości. Jednak Deleuze idzie dalej. Akt śmiechu jako intensywność, jako gra si $^{32}$, jak pisze w Myśli nomadycznej, niczym nietzscheańska ścieżka jest aktem 'nadania życia' czystej potencjalności.

Wzrok Agambena jest inny. Agambena Wspólnota, która nadchodzi 'zjawia się ozłoconym dniem a spełnienie następuje bez lamentu' ${ }^{\prime 3}$. Jest to wzrok samozadowolenia, owa możliwość równoczesnego istnienia w każdym i wszystkich światach równocześnie, co zostało pokazane na rysunku. A wracając do wiersza, byłaby to sytuacja wędrowca, który obiera obie drogi równocześnie. Wzrok Derridy spowijają łzy. Wzrok Deleuze'a, tak jak wzrok Derridy, ani widzi, ani nie widzi: jest obojętny na mglisty krajobraz. Lecz Deleuze również uśmiecha się. Jest to jednak uśmiech przez łzy, jako że krajobraz Deleuzjańskich intuicji to ten, gdzie struktura jest krucha, niestabilna, nietrwała. Jest ona raczej ‘stawaniem się’ niż ‘byciem jako takim'. Deleuze jest świadomy 'cięcia', owej przedustawnej, przedistniejącej rany. Jest to rana - używają słów ukochanego przez filozofa Joe Bosqueta - która czeka, aby być wcieloną. Jednak siła uśmiechu sprawia, że delikatna harmonia zostaje osiągnięta.

Kończąc cokolwiek z emfazą: moment, gdy wzrok 'zrozumie' - to moment łez, jako że jest to zrozumienie 'cięcia'. Gest uśmiechu nad własnymi łzami to gest autoreferencyjny, niczym spełniony paradoks. Rzekłabym, że jest to moment Alicji z Krainy Czarów jako realnie istniejącej, egzystującej

31 J. Derrida Memories of the Blind, The University of Chicago Press, Chicago 1993, s. 127.

G. Deleuze Desert Islands and Other Texts, Semiotext(e), London 2002, s. 256: „An aphorism is a play of forces, a state of forces what are always exterior to one another. An aphorism doesn't mean anything, it signifies nothing, and no more has a signifier that a signified".

Autorka prezentuje własne tłumaczenie, gdyż polskie tłumaczenie („Zjawia się ozłoconym dniem, a spełnienie nie brzmi skargą") jest nieprecyzyjne. W wersji włoskiej ów fragment brzmi: " «Essa» si mostra con giorno d'oro e la compiutezza e senza lamento" a w angielskiej jest to "the fulfilment without lament". Na marginesie, Agamben - najprawdopodobniej - niedokładnie cytował wiersz Holderlina. Najprawdopodobniej chodzi o wiersz Wesołe życie, którego dwa ostatnie wersy w przekładzie Antoniego Libery brzmią "Bywaj, wracam już do siebie, złotym winem sycić wzrok", a w niemieckim oryginale ów wiersz Das frohliche Leben zakańczają wersy: "Geh' ich heim zulezt, haushaltig, Dort nach goldem Wein zu sehen". 
w prawdziwym świecie. Zawsze jednak to będzie albo NibyAlicja albo Nibyświat.

I powracając do wiersza Frosta: gdy wędrowiec uśmiecha się do własnych łez, to nie jest to akt wyboru, akt oznaczania. Jest to akt życia. „Miłość życia, która mówi tak śmierci", mówi Deleuze w Dialogach.

«Un amour de la vie qui peut dire oui à la mort »34.

\section{Abstract}

\section{Ewa Szumilewicz}

INSTITUTE OF PHILOSOPHY AND SOCIOLOGY OF THE POLISH ACADEMY OF SCIENCES

On Agamben and Deleuze's Potentiality

Szumilewicz examines Agamben and Deleuze's treatment of the question of potentiality. Drawing on the basic laws of formal logic, she sheds light on the logical error in Agamben's argumentation on his position regarding the question of potentiality. She also relates Deleuze's intuitions - metaphorically - to concepts that belong to contemporary physics.

\section{Keywords}

Agamben, logical error, Deleuze, potentiality, contemporary physics 